\title{
RAINFALL-RUNOFF MODELLING IN SMALL AND MIDDLE- LARGE CATCHMENTS - AN OVERVIEW
}

\begin{abstract}
M. J e níč e k: Rainfall-runoff modelling in small and middle-large catchments - an overview. - Geografie-Sborník ČGS, 111, 3, pp. 305-313 (2006). - A rainfall-runoff modelling is nowadays a dynamically developing department of hydrology and water management. This development is caused by a rapid progress of computers and information technologies. This evolution provides the mankind with new possibilities to use water as its basic need and at the same time to evolve an effective protection against it. The aim of this article is to give some basic information about rainfall-runoff modelling, various approaches to it, methods and possibilities of application. This kind of information may help the user with the choice of the suitable rainfall-runoff model. Rainfall-runoff or hydraulic models have many different applications, e.g. in operational hydrology, water resource management or in research. Typical structure of any rainfall-runoff model, come out from a simplified catchment structure as a system of vertical ordered reservoirs, which form a linear cascade model. The main reservoirs are precipitation, evapotranspiration (together with interception), direct runoff, runoff in unsaturated zone (interflow), base flow and channel flow. For computation of processes running in each of these reservoirs (filling or drainage), many equations (model techniques) are applied. This structure and presented modelling techniques are used in the most common models like HEC-HMS, MIKE-SHE, Sacramento (SAC-SMA), NASIM, HBV and many others.

KEY WORDS: modelling of hydrological processes - mathematical modelling - rainfallrunoff models - hydraulic models - floods.
\end{abstract}

The presented research was funded by the Research Plan MSM 0021620831 "Geographical Systems and Risk Processes in Context of Global Changes and European Integration" of the Czech Ministry of Education and Research Project VaV-SM/2/57/05 "Long-term changes of river ecosystems in floodplains affected by extreme floods" of the Ministry of Environment of the Czech Republic which is fully appreciated by the author.

\section{Introduction}

Mathematical representation of rainfall-runoff process has a long history, but until 80s of the last century became, due to rapid computer technology development, an important instrument for hydrologist and water managers, whether for hydrology forecast or for design purposes.

Mathematical model of rainfall-runoff process (R-R process) represents simplified quantitative relation between input and output variables of the certain hydrological system (Daňhelka et al. 2002). This relation is defined as a system of mainly physical processes affecting input values and transforms them to output values. This means, in mathematical sense, a solution algorithm of equation system. It describes system structure and system behaviour (Clarke 1973, In: Fleming 1979).

Currently many authors deal with the issue of rainfall-runoff and hydrodynamic modelling, both in Czechia and in the world. There are e.g. 
Buchtele (2002); Daňhelka et al. (2002); Kulhavý, Kovář (2002); Řičicová, Krejčí (2002) or Starý (2004). Hydrologic and hydraulics models are also used in many Czech institutions like Czech Hydrometeorological Institute, Water Research Institute, Academy of Science and some universities.

But the main research centre lies in the world, above all in the articles and publications of Beven (1996, 2001); Bergström (1995); Blöschl, Grayson (2002); Refsgaard, Storm (1996); Smith et al. (2000, 2004) and many others. From these studies an effort to accurate analysis of precipitation input (mainly radar estimations) is evident. Very important is also a development of calibration methods, especially automatic optimisation of input parameters. Developing of methods, which describe processes in the soil column (unsaturated soil profile), is also essential. Substantial progress for both R-R and routing models was DMIP project (Distributed Model Intercomparison Project). The aim of this project was a comparison of different R-R and hydrodynamic models and their approaches. Results were published in Journal of hydrology, Volume 298 (October 1994). Theoretical frame of described part of hydrology gives some articles and publications of Clarke (1973), O'Connor (1976), Bear (1972) and many others. Some of this approaches were implemented in methodology of the WMO (World Meteorological Organisation), e.g. Becker, Serban (1990) or WMO (1983).

Over time of models application, their different approaches to a catchment description, a several groups of models were turned out. Most common is the classification according to the WMO (World Meteorological Organisation) described by Becker, Serban (1990). There we can distinguish several groups of classification criterions. The most common of this criterion is a degree of causality (deterministic and stochastic models) and time or space discretisation (continually vs. event models, lumped vs. distributed or semi-distributed models).

\section{Means of application}

Rainfall-runoff or hydraulic models have many different applications. It is possible to distinguish three main categories.

First area of application is operational hydrology. Input data are formed, besides state variables, by real-time data from automatic stations or sometimes from meteorological radars. Data are automatically (after checking by hydrologist) given to a model and priority is a velocity of their processing. A result is a short-time forecast of water stage or discharge. Practically it means more specialized models (wave routing or subsurface flow model) which together with software for data collecting and analyses form a Flood Forecast System (FFS).

Second area forms partly long-time solutions of flood protection (dams, dry polders or another flood or drought protection measures) and partly are R$\mathrm{R}$ and hydrodynamic models useful by building of several technical water management project like canals, irrigations, cleaners, weirs or bridges.

Another type of application is a possibility for additional development of models, research of particular components of rainfall-runoff process and their more accurate description. For these purposes some experimental catchments use to be created with above standard network of measurement stations.

Rainfall-runoff model results can be also applied as an input of other applications like pollution diffusion models. Interesting could be also application in climate change impact simulations. 


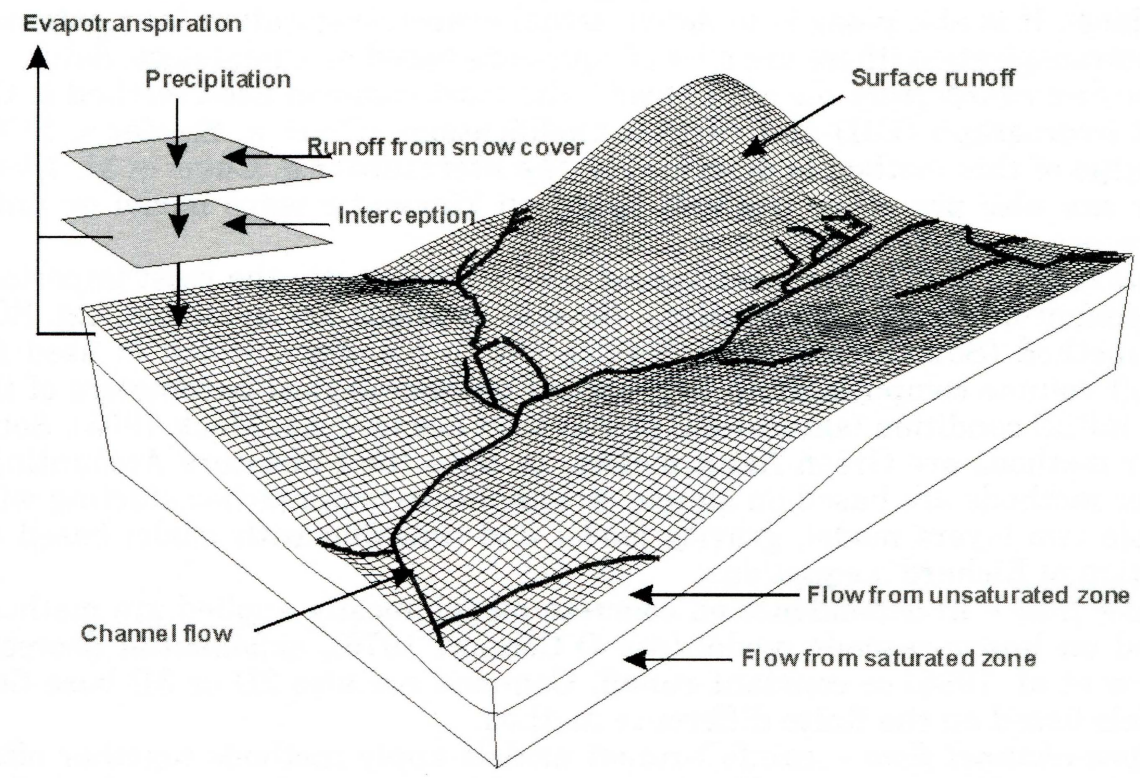

Fig. 1 - General structure of a hydrological model

Here are some concrete types of hydrological tasks, where an application of rainfall-runoff model is possible:

- flood wave run simulation of any time or space step, both in natural and urban areas

- flood protection project designing, support of crisis management systems

- low flows modelling, e.g. for drought period or pollution diffusion

- support of reservoirs, polders, canals or irrigation management

- hydrologic balance computation

- long-time period scenarios, base on climate change models

- statistic parameters computation (excess probability, etc.).

\section{General structure of a Rainfall-Runoff model}

General characteristic of the most of R-R models is dividing of the catchment to several zones, mainly vertical ordered. These zones are with help of the linear cascade model (O'Connor 1976) computed. Their simplified structure is displayed in the figure 1.

For computation of processes running in each of these reservoirs (filling or drainage), many equations (model techniques) are applied.

Precipitation (both rain and snow) - they are entered into models in the form of time series from meteorological stations (as a point rain) or sometimes meteorological radars (as an area rain). For estimation of the snow precipitation influence methods of temperature index, degree-day method or energy balance are applied.

Evapotranspiration (include interception) - actual evapotranspiration and interception are computed from time series from climatologic stations if they are 
available. It is also possible to derive actual evapotranspiration from potential evapotranspiration (there are a lot of equations based on climatologic data).

Surface runoff from the catchment - the most common used method is the Unit hydrograph (UH) and various modifications (Clark's, Snyder's, SCS). Principe of this method is described in the literature (e.g. Chow et al. 1988). User can also use other methods based on kinematic wave model or finite difference method.

Subsurface flow in the unsaturated zone - it is mostly the most important component of runoff concentration. Several methods are available, e.g. SCS CN method (Soil Conservation Service Curve Number), which is used for runoff volume computation in dependence on hydrological parameters of the soil, initial condition (saturation) or soil land use (see e.g. Mack 1995). Some other methods are Green-Ampt method or SMA (Soil Moisture Accounting). Other methods are based on simple or complicated approaches starting with simple two layers model, gravity model and finishing with model based on solution of Richard's equations.

Base flow - in dependence on concrete model, mostly applied are methods based on linear cascade model (see O'Connor, 1976), exponential decrease (Chow et al. 1988) or constant runoff. Common are also 2D or 3D base flow models based on the finite difference method.

Open-channel flow - rainfall-runoff models apply methods together often called hydrologic routing. There are e.g. Muskingum-Cunge method, Lag model, kinematic wave model or transport diffusion equation. These methods are mainly based on a solution of basic equations of open-channel flow - continuity and momentum equations. There are together known as St. Venant's equations (see e.g. Feldman 2000).

Water control facilities - in R-R model are also some possibilities for modelling water control facilities, such as reservoirs, polders or diversion.

\section{Characteristic of some rainfall-runoff models}

\section{1. M I K E - S H E}

Rainfall-runoff model MIKE-SHE of Danish firm DHI (Danish Hydraulic Institute) belongs to a group of conceptual distributed or semi-distributed models. It consists of several components computing a volume and distribution of water during particular phases of runoff process:

- Precipitation - serves as an input data. Both liquid and compact.

- Evapotranspiration, included interception (input data)

- Surface flow - based on 2D finite difference method.

- Channel flow - 1D routing model MIKE11 is applied. This model provides several methods, such as Muskingum, Transport Diffusion Equation or method based on solution of St. Venant's equations.

- Subsurface flow in unsaturated zone - simple two-layer model, gravity flow model or on Richard's equation based model are available.

- Base flow - MIKE-SHE contains 2D and 3D base flow model based on the finite differences method.

For the soil model a database including soil hydrology characteristic (porosity, hydraulic conductivity, etc.) was created. Also two extensions of ESRI software ArcView 3.x or ArcGIS 9.1 were created. These extensions 
work with the input data. First, Geomodel (for ArcGIS 9.1) serve for geological characteristics interpretation. Second, DaisyGIS is a conceptual model (for ArcView 3.x) for description of all important processes bounded on agricultural ecosystem (water, heat or nutrients transport).

In the model both manual and automatic calibration is possible. For automatic calibration the tool AUTOCAL was developed. This tool allows optimisation according to initial and border conditions.

\subsection{HEC - HMS}

Model HEC-HMS (Hydrologic Engineering Centre - Hydrologic Modelling System) is a continuator of model HEC-1 developing since 60 s by the US Army. It is mainly lumped model. Its great advantage is that fact, that it is a freeware, also in Internet available. The basic components are following:

- Runoff-volume models - includes some methods, such as SCS CN (Soil Conservation Service Curve Number), Green-Ampt or SMA (Soil Moisture Accounting).

- Direct-runoff models - for direct runoff computation a Unit Hydrograph method (UH) or its various modifications is used. (Clark's, Snyder's, SCS). For user a method of kinematic wave is also available.

- Baseflow models - a user can choose, for instance, linear reservoir model, exponential decrease, or constant runoff model.

- Routing models - there are Muskingum-Cung model, Lag model, kinematic wave model or their modifications available.

- Others models - in special cases there are also possible to simulate the reservoirs, weirs, etc.

For HEC-HMS model an extension of ArcView 3.x called HEC-GeoHMS was also created. This extension is able to derive some basic hydrological characteristics of the basin - watersheds, water flow directions, flow accumulations, slopes, etc.

With HMS both manual and automatic calibration of parameters is possible. Regarding the type of a model (suitable for catchments up to $500 \mathrm{~km}^{2}$ ) the calibration takes place on short flood events.

\subsection{N A S I M}

Rainfall-runoff model NASIM (Niederschlag-Abfluss Simulation Model) made by German firm Hydrotec is developing since 80 s and belongs to a group of conceptual, deterministic, semi-distributed models. The basic components are following:

- Rainfall generation (Belastungsbildung) - for differentiation of liquid and compact precipitation a combined method "Temperature Index/Snow Compaction" is applied.

- Space distribution of precipitation (Belastungsverteilung) - conversion of point values to area precipitation.

- Runoff components separation (Belastungsaufteilung) - quantification of runoff components (interception, evapotranspiration, accumulation in depressions, infiltration, percolation).

- Runoff concentration (Abflusskonzentration) - water flow in unsaturated (interflow) and saturated (baseflow) zone of the soil profile is by linear or nonlinear cascade model described. For surface runoff a method based on Unit hydrograph was created. 
- Channel flow (Wellentransport) - by channel flow description an adjusted Kalinin-Miljukov method is applied.

For data analysis some extensions for ArcView 3.x were created. Most important are extensions "Zfl" and "Verschneidung". First makes time-area function of the catchment. Second works up basic characteristic of the catchment. Useful are also extensions for results interpretation. Together with model a software Time-View for time series visualization and interpretation was made.

For model calibration, only a program unit for manual calibration was developed. By calibration, the biggest change is mostly registered by those parameters, which express hydrological properties of the soil - vertical and horizontal hydraulic conductivity, porosity, infiltration rate, etc. (Jeníček 2005). In the future, also an automatic calibration will be applied.

\subsection{SAC - SMA ( Sacramento)}

Sacramento-Soil Moisture Accounting, a part of the model technique library of the NWSRFS system (National Weather Service River Forecast System), is developing since 70s by a US National Weather Service (NWS; Burnash 1995). In Czechia is this model a part of the model techniques library of the Aqualog forecast system. Aqualog is used in the Czech Hydrometeorological Institute (CHMI) as a forecast system of the Vltava and Elbe Rivers basins. Every catchment is divided into several zones, which are connected into a reservoirs system. Basis of these zones are upper and lower zone. Upper zone contains tension and free water, lower zone contains primary free and tension water and supplementary free and tension water). Excess water flows away in a form of several types of runoff:

- direct runoff

- surface runoff

- subsurface runoff (interflow)

- primary base flow

- supplementary base flow.

Whereas Sacramento is a soil moisture model the most important data are soil data - hydraulic conductivity, porosity, etc.

Sacramento supports both manual and automatic calibration. Together 24 parameters can be calibrated, which can be classified according to a particular zone.

\subsection{H B V}

Hydrologic model HBV is developing since the beginning of 70 s in the Swedish Meteorological and Hydrological Institute (Bergström 1995). It is a part of the modelling system IHMS (Integrated Hydrological Modelling System). Although this model is not so used in Czechia, abroad is very often applied. Typical components are:

- snow Unit - computation is base on simple degree-day method

- soil Moisture Unit - main computation component of runoff concentration

- runoff Origin Unit - base on the Unit Hydrograph method

- reservoir Unit.

In HBV model a manual calibration is used. For most of time-series a day step of calibration is used, for evapotranspiration time-series a month step is applied. For the calibration period, information about discharges in outlet profile is needed. 


\section{Conclusion}

From this article is clear, that for modelling of rainfall-runoff processes many methods are available. These methods are possible to use by solution of various types of hydrological tasks, such as operational hydrology, flood or drought protection or pollution transport modelling. One of the first steps by the project solution is a choice of the model, which will be suitable for concrete hydrological task. The user should take into account some criterions and claims to a model according to the data which model needs, type of hydrological problem (if model is needed for operative forecast or modelling of catastrophic scenarios, for instance), size of a catchment, connection to GIS or other software for collecting, analysing or presentation of the data and results. The user should also know if data which model needs are available for the catchment. Also previous references, support and of course a price are very important. For more extensive catchments (over $100 \mathrm{~km}^{2}$ ) could be also a connection with a routing model for flood wave progress simulation useful. In department of physical geography and geoecology was after consideration of all described factors models MIKE-SHE together with MIKE 11 and HEC-HMS together with HEC-RAS chosen. It is also studied the possibility of using Czech hydrodynamic model Hydrocheck and the $R-R$ model WMS.

\section{References:}

BEAR, J. (1972): Dynamics of fluids in porous media. American Elsevier publishing, New York, $764 \mathrm{p}$.

BECKER, A., SERBAN, P. (1990): Hydrological models for water - resources system design and operation. Operational Hydrology Report No. 34, WMO, Geneva, 80 p.

BERGSTRÖM, S (1995): The HBV Model. In: Singh, V. P. (ed.): Computer models of watershed hydrology. Water Resourse Publications, Highland Ranch, pp. 443-476.

BEVEN, K.J. (1996): A discussion of distributed hydrological modelling. In: Abbott, M. B., Refsgaard, J. C. (1996): Distributed hydrological modelling. Kluwer, Dordrecht, pp. 255-279.

BEVEN, K. J. (2001): Rainfall-Runoff Modelling, The Primer. John Wiley \& Sons, Chichester, $360 \mathrm{p}$.

BLÖSCHL G., GRAYSON R. (2002): Flächendetaillierte Niederschlag-Abfluss Modellierung. In: Wiener Mitteilungen - Band 164 - Niederschlag-Abfluss Modellierung - Simulation und Prognose, Technische Universität Wien, pp. 33-55.

BUCHTELE, J. (2002): Uvod k metodám a modelům hydrologických předpovědí. In: Patera, A. et al.: Povodně: prognózy, vodní toky a krajina. CVUT, Praha, pp. 33-35.

BURNASH, R. J. C. (1995): The NWS River Forecast System - catchment modeling. In: Singh, V. P. (ed.): Computer Models of Watershed Hydrology. Water Resourse Publications, Highland Ranch, pp. 311-366.

CLARKE, R. T. (1973): Mathematical models in hydrology. Irrigation and Drainage paper No. 19, FAO, Rome.

CHOW, V. T., MAIDMENT, D. R., MAYS, L. W. (1988): Applied hydrology. McGraw-Hill, New York.

DAŇHELKA, J., KREJČÍ, J., ŠÁLEK, M., ŠERCL, P., ZEZULÁK, J. (2002): Posouzení vhodnosti aplikace srážko-odtokových modelů s ohledem na simulaci povodňových stavů pro lokality na území ČR. ČZÚ, Praha, 214 p.

FELDMAN, A. D. (ed., 2000): Hydrologic Modeling System HEC-HMS - Technical Reference Manual. US Army Corps of Engineers, Washington, 149 p.

FLEMING, G. (1979): Deterministic models in hydrology. Irrigation and Drainage paper, 32, FAO, Rome, 80 p.

JENÍČEK, M. (2005): Aplikace matematického modelu NASIM pro simulaci srážkoodtokových poměrů v povodí Černé vody. Thesis. PřF UK, 104 p. 
KULHAVÝ, Z., KOVÁŘ, P. (2002): Využití modelů hydrologické bilance pro malá povodí. VÚMOP, Praha, $123 \mathrm{p}$.

LANGHAMMER, J. et al. (2006): Změny krajiny jako ovlivňující faktor průběhu a projevů extrémních povodní. PřF UK, Praha, 209 p.

MACK, M. J. (1995): HER - Hydrologic evaluation of runoff; The Soil Conservation Service Curve Number technique as an interactive computer model. Computers \& Geosciences, Vol. 21, Issue 8, pp. 929-935.

O'CONNOR, K. M. (1976): A discrete linear cascade model for hydrology. Journal of Hydrology, 29, pp. 203-242.

REFSGAARD, J. C., STORM, B. (1996): Construction, calibration and validation of hydrological models. In: Abbott M. B., Refsgaard J. C.: Distributed hydrological modelling. Kluwer, Dordrecht, pp. 41-54.

ŘIČICOVÁ, P., KREJČ́, J. (2002): Využití hydrologických modelů a perspektivy jejich rozvoje u nás. In: Počasí - moderní předpovědní metody, prevence a snižování následků katastrof, ČHMÚ, Praha, pp. 36-41.

SMITH, M. B., KOREN, V. I., WELLS, E., WANG, D., ZHANG, Z. (2000): Evaluation of the advantages of the continuous SAC-SMA model over an event API model. 15th Conference on Hydrology 9.1-4.1.2000, Long Beach, CA.

SMITH, M. B., KOREN, V. I., ZHANG, Z., REED, S. M., PAN, J-J., MOREDA, F. (2004): Runoff response to spatial variability of precipitation: an analysis of observed data. Journal of Hydrology, 298, pp 267-286.

STARÝ, M. (2004): Užití umělých neuronových sítí v aplikované hydrologii - zkrácená verze habilitační práce. VÚT, Brno, $40 \mathrm{~s}$.

WMO-No. 168 (1983): Guide to hydrological practices, Volume II - Analysis, Forecasting and other application. WMO, Geneva.

\section{Shrnutí}

\section{MODELOVÁNÍ SRÁŽKO-ODTOKOVÝCH PROCESŮ NA MALÝCH A STŘEDNĚ VELKÝCH POVODÍCH}

Matematická reprezentace srážko-odtokového procesu má dlouhou historii, ale teprve zhruba od 80. let minulého století se díky postupnému rozvoji počítačových technologií stává významným nástrojem hydrologů a vodohospodářư, at’ už pro operativní předpověđ nebo pro návrhové účely.

Cílem příspěvku je podat základní informace o přístupech ke srážko-odtokovému modelování, jednotlivých metodách a také charakterizovat některé nejčastěji používané modely, jako jsou MIKE-SHE, HEC-HMS, NASIM, Sacramento a HBV.

Problematikou využití hydrologických a jednorozměrných hydraulických modelů se v současné době zabývá řada autorů. Z českých jsou to např́íklad Buchtele (2002), Daňhelka a kol. (2002); Kulhavý, Kovář (2002); Řičicová, Krejčí (2002) nebo Starý (2004). Hlavní těžiště výzkumu a vývoje všech typů hydrologických modelů spočívá v zahraničí, především v pracích Bevena (1996, 2001); Bergströma (1995); Blöschla, Graysona (2002); Refsgaarda, Storma (1996); Smithe a kol. (2000, 2004) a dalších, kteří aplikovali nejrůznější hydrologické modely a výrazně tím přispěli $\mathrm{k}$ vývoji metod popisující srážko-odtokový proces. Tyto práce dokazují, že důraz je kladen především na přesnější zpracování srážkových polí jako vstupu do modelu (hlavně v podobě radarových odhadů). Významný prostor je také věnován postupům kalibrace modelu, především pak procesu automatické optimalizace vstupních parametrů. Zásadní je také vývoj metod popisujících proudění v nenasycené zóně půdního profilu (model půdní vlhkosti). Významným příspěvkem do problematiky jak hydrologických, tak hydraulických modelů byl projekt DMIP (Distributed Model Intercomparison Project), který si dal za cíl srovnání několika srážko-odtokových modelů a jejich přístupů. Výsledky byly publikovány $\mathrm{v}$ Journal of Hydrology, 298 (ř́jen 2004). Mnoho z těchto i dř́ívějších přístupů je zahrnuto $\mathrm{v}$ metodikách a doporučeních WMO (World Meteorological Organisation), například Becker, Serban (1990) nebo WMO (1983).

Použití matematických modelů je možné rozdělit do tři hlavních kategorií podle charakteru daného úkolu. První oblast využití je operativní hydrologie, druhou oblast tvoří jednak dlouhodobější řešení protipovodňové ochrany a také řešení nejrůznějších vodohospodářských staveb. Pod třetí kategorií využití hydrologického modelu se skrývají možnosti dalšího vývoje modelu, výzkum jednotlivých komponent srážko-odtokového procesu a jejich přesnější popis. 
Výstupy $\mathrm{z}$ hydrologického modelu mohou sloužit jako vstupní veličiny dalších modelů (například modelů šírení znečištění ve vodním prostředí) a naopak mohou mít hydrologické modely návaznost na jiné projekty, například odhad vlivu klimatických změn na srážkoodtokové poměry v povodí.

Obecnou charakteristikou většiny modelů je rozdělení povodí na několik, většinou vertikálně uspořádaných zón, které jsou počítány konceptem lineární nádrže. Jedná se o následující komponenty:

Srážky (deštové $i$ sněhové) - jde o vstupní data ve formě časových řad ze srážkoměrných stanic. Pro výpočet sněhových dat bylo vyvinuto množství metod.

Evaporace, včetně intercepce - aktuální evapotranspirace a intercepce bývá počítána z časových řad, pokud jsou uživatelem zadány.

Pourchový odtok $z$ povodí - nejčastěji je využíván jednotkový hydrogram (Unit Hydrograph). Uživatel také může využít model kinematické vlny nebo metodu konečných diferencí.

Podpovrchový odtok $v$ nenasycené zóně pưdního profilu - často se jedná o nejdůležitější komponentu koncentrace odtoku. K dispozici bývá více metod např́klad metoda SCS CN křivek (Soil Conservation Service Curve Number). Jiné metody jsou např́klad Green-Ampt metoda nebo SMA (Soil Moisture Accounting). Další metody jsou založeny na jednodušších i poměrně složitých postupech od dvouvrstvého modelu, přes gravitační model proudění, až po model založený na řešení Richardsovy rovnice.

Podzemní odtok - v závislosti na konkrétním modelu jsou často používanými metodami model lineární nádrže, exponenciálního poklesu nebo konstantního odtoku. Obvyklý je také 2D a 3D model proudění podzemní vody založený na metodě konečných diferencí.

Odtok v korytě - rozšířenými modely jsou například Muskingum-Cunge, Lag model, model kinematické vlny nebo transportní difuzní rovnice. Tyto metody jsou založeny na řešení rovnice kontinuity a momentové rovnice (St. Venantovy rovnice).

$\mathrm{Z}$ uvedeného přehledu je zřejmé, že $\mathbf{k}$ modelování srážko-odtokových procesů je $\mathrm{k}$ dispozici celá řada př́stupů, které je možné použít pro řešení úkolů spojených s problematikou povodní. Dủležitý je výběr vhodného modelu. Ten musí odpovídat charakteru projektu, tedy účelu zpracování. Je potřeba také dopředu vědět, jsou-li data, která model vyžaduje, dostupná. Pro řešení projektů na středně velkých povodích (nad cca $100 \mathrm{~km}^{2}$ ) je již vhodné propojení srážko-odtokového modelu s podrobnějším korytovým modelem. Při zpracování dat a interpretaci výsledků je žádoucí také schopnost komunikace modelu, či modelového systému s geoinformačními systémy. Aplikace hydrologického modelu je většinou finančně i časově velmi náročný proces a je tedy nutné zvážit zda se investované peníze a čas nakonec vyplatí.

Obr. 1 - Obecná struktura hydrologického modelu

(Author is with Charles University in Prague, Faculty of Science, Department of Physical Geography and Geoecology, Albertov 6, 12843 Praha 2, Czechia; e-mail:jenicek@natur.cuni.cz.) 